\title{
Sunshine on KOL : a retrospective study about financial ties be- tween medical key opinion leaders and pharmaceutical industry in France.
}

\author{
Marie CLINCKEMAILLIE, MD (ORCID: 0000-0001-6643-001X) ${ }^{1}$, Alexandre SCANFF, \\ MD (ORCID: 0000-0001-5419-817X) ${ }^{2}$, Florian NAUDET, PhD (ORCID: 0000-0003-3760- \\ $3801)^{2}$, Adriaan BARBAROUX, MD (ORCID: 0000-0002-9243-6922) ${ }^{3}$. \\ ${ }^{1}$ Université Cote d'Azur, Département d'Enseignement et de Recherche en Médecine Géné- \\ rale, RETINES, HEALTHY, France \\ ${ }^{2}$ Univ Rennes, CHU Rennes, Inserm, CIC 1414 [(Centre d'Investigation Clinique de \\ Rennes)], F- 35000 Rennes, France \\ ${ }^{3}$ Université Cote d'Azur, Département d'Enseignement et de Recherche en Médecine Géné- \\ rale, RETINES, LAPCOS, HEALTHY, France
}

Corresponding author : A. Barbaroux

Adriaan.barbaroux@univ-cotedazur.fr; 2bis Avenue Durante, 06000 Nice

Word count of the manuscript text : 2985 


\section{ABSTRACT \\ Objective}

To investigate the nature, extent and evolution of financial relationships between key opinion leaders (KOL) or non-KOL physicians and pharmaceutical and device companies in France.

\section{Design}

Retrospective and descriptive study

\section{Setting}

All doctors practicing in France, with a focus on $548 \mathrm{KOL}$ defined as board members of all the professional medical associations having published clinical practice guidelines in 2018 or 2019. These 99 associations were identified by the cross-checking of 3 databases.

\section{Main outcome measures}

The number and the amount of gifts (year by year since 2014), remunerations and agreements (year by year since 2017).

\section{Results}

Physicians had $818 \mathrm{~m} €(\$ 936 \mathrm{~m}, £ 741 \mathrm{~m}$ ) of gifts declared from 2014 to $2019.83 \%$ of KOL had such links of interest. The 548 identified KOL represented $0.24 \%$ of physicians in France but received $1.5 \%$ of the total amount of gifts, i.e. $€ 12.3 \mathrm{~m}(\$ 14 \mathrm{~m}, £ 11 \mathrm{~m}$ or $€ 3700$ per capita per year).

Physicians had $125 \mathrm{~m} €(\$ 143 \mathrm{~m}$ and $114 \mathrm{~m} £$ ) of agreements declared from 2017 to 2019. The $548 \mathrm{KOL}$ received $0.72 \%$ of the agreements and $2.5 \%$ of the value of the agreements, i.e. $3.1 \mathrm{~m} €(\$ 3.6 \mathrm{~m}, £ 2.8 \mathrm{~m})$ or $€ 1900$ per capita per year $(\$ 2200, £ 1700)$.

Physicians had 156m€ (\$178m and 141mf) of remunerations declared from 2017 to 2019. The 548 identified KOL received $4.4 \%$ of the total value of remunerations to physicians, i.e. $6.8 \mathrm{~m} €(\$ 7.8 \mathrm{~m}, £ 6.2 \mathrm{~m})$ or $4100 €$ per capita per year $(\$ 4800, £ 3700)$.

Almost every professional medical associations (99\%) had in their board at least one KOL with a financial tie.

\section{Conclusion}

Financial relationships between KOL and the industry in France are extensive, KOL have much more financial ties than non-KOL practitioners. The main limit of this study arises from the quality of information provided on the French Transparency in Healthcare database.

Pre-registration: osf.io/m8syh

\section{Strengths and limitations of this study}

This is the first attempt to provide data on the extent of the links of interest between opinion leaders and pharmaceutical industry in France.

Author crossed the nationwide databases of financial ties with three databases of professional medical associations.

All medical doctors practicing in France were inclused, with a focus on $548 \mathrm{KOL}$ defined as board members of all the professional medical associations having published clinical practice guidelines in 2018 or 2019.

These 99 associations were identified by the cross-checking of 3 different catalogs of French professional associations.

The major links between key opinion leaders and industry ask the question of the independence of the experts, and raises concern that guidelines can be influenced by industry.

Keywords :

Conflict Of Interests - Key Opinion Leaders - public health - quality in health care - medical ethics 


\section{INTRODUCTION}

Financial ties between healthcare workers and pharmaceutical indusctry may affect every aspects of medical activity, from research to clinical practice. Clinical trials and meta-analyses sponsored by the pharmaceutical industry are more likely to conclude that drugs are effective than non-sponsored trials. ${ }^{1}$ Industry's transfers of value to physicians have been shown to be associated with more expensive, more frequent and of lower quality prescriptions ${ }^{2-5}$. Recommendations for clinical practice, which define the diagnostic criteria and treatment of the diseases, can also be under influence, since their authors often have ties with the industry. ${ }^{6-11}$

Following the example of the USA with the US Physician Payments Sunshine Act, France created the Transparency in Healthcare public database (transparence.santé.gouv.fr) in 2014. ${ }^{12-14}$ Pharmaceutical and medical device industries are required by law to disclose gifts, agreements and remunerations they transfer to healthcare professionals in France.

The term "Key Opinion Leaders" (KOL) refers to physicians who influence their peers' medical practice, including but not limited to prescribing behaviour. It was coined by sociologists who demonstrated that people changed their opinions more because of some individuals in their networks than because of media or advertising: the influence of the physicians' social networks is major to make them adopt a new drug. ${ }^{15,16}$ Pharmaceutical companies hire KOLs at different stages of the drug development process, from clinical trials to promotion. ${ }^{17,18}$ Typically, KOLs are physicians or researchers who are respected in their field and recognized for their work, such as broad members of professional medical associations. $18-22$

Major ties between leaders of professional medical associations and the pharmaceutical industry have recently been described in North America. ${ }^{10,11}$ In France, these links had never been studied yet.

In this study we described the nature and evolution of gifts, agreements and remunerations perceived by key opinion leaders (KOL) and other physicians using the data from the Transparency in Healthcare database. We also grouped gifts, agreements and remunerations perceived by these KOL for each professional medical association they belong to.

\section{METHODS}

As per our protocol (registration number: osf.io/m8syh), we conducted a retrospective study of the financial relationships between industry and board members of the national professional medical associations publishing clinical practice guidelines.

\section{Identifying professional medical associations}

Professional medical associations were defined as any group of physicians who published clinical practice guidelines in France. One author (MC) built the list of eligible associations by cross-checking three different databases: the "Catalogue et index des sites médicaux de langue française" (CISMEF) ${ }^{23}$ ), "Le Parisien" review professional medical associations catalogue ${ }^{24}$ ) and the "Bibliothèque Médicale AF Lemanissier" (BMLweb) ${ }^{25}$ ). We included only national associations and excluded association titled as concerning "rare disease". Then, MC searched for those who had published at least one clinical practice recommendation in 2018 or 2019 using Google scholar, academic medical library of the general hospital of Le Mans and CISMEF.

\section{Identifying Key Opinion Leaders}

Using each professional medical association's website, MC identified between Octo- 
ber 2018 and May 2020 all physicians who were board members.

KOL were defined as members of the association's board or governing council but not of subcommittees. KOL were identified by their name, medical specialty and city of practice, on the medical association website then if missing on google. Discrepancies and uncertainties were resolved by discussion with a second author $(\mathrm{AB})$.

The Transparency in Healthcare database was downloaded on may 18, 2020 from the website EurosForDocs ${ }^{26}$. EurosForDocs is a tool inspired by the American website DollarsForDocs. EurosForDocs aims to help querying and understanding the Transparency in Healthcare database by cleaning and grouping payments by categories and beneficiaries. It also harmonizes the identification of doctors using their unique identification number in the National Healthcare Professional Registry : the "RPPS" (Répertoire Partagé des Professionnels de Santé). RPPS of the KOL were identified by AS from Health-Directory database and Transparency in Healthcare database. Uncertainties were resolved by manual inspection (MC).

\section{Identifying and extracting payment details}

By using the RPPS unique identification number, data on payments for the identified leaders ${ }^{27}$ were extracted, using categories within the database: gifts, agreements and remunerations. We took into consideration the data from the date they were obligatory to declare: gifts from January 1, 2014 to December 31, 2019 and agreements and remunerations from January 1, 2017 to December 31, 2019.

"Gifts" include anything that is granted without consideration, in kind or in cash, directly or indirectly, of an amount greater than or equal to $10 €(\$ 11,4)$ including taxes. "Remunerations" represent the payment by companies for work or services, of an amount greater than or equal to $10 €$. "Conventions" are agreements involving obligations on both sides: participation in a congress, research or clinical trial activity, training action, etc. The characteristics and date from where the payments were mandatory to declare are presented in table $\mathbf{1}$.

\section{< PLEASE INSERT TABLE 1 HERE >}

\section{Outcome measures and descriptive analyses}

The primary outcome was the total amount of gifts received by all the medical physicians and by the identified KOL, year by year since 2014 .

A secondary outcome was the number and amount of the 2 additional categories of payments available after 2017 (i.e. agreements and remunerations), year by year since 2017.

Distribution of individual results of KOL pooled for each professional medical association is also presented. Quantitative data were described using median (inter-quartile range, IQR) rather than mean to be less biased by the influence of extreme observations. Binary outcomes were described using n (percentage). All analyses were performed using R. ${ }^{28}$

\section{Changes to protocol}

The secondary outcome including agreements and remunerations was not part of the protocol as these declarations were not mandatory before 2017. However, after having noted that remunerations represented more than 3 times the yearly amount of gifts, it was decided to include agreements and remunerations because we might have missed an important part of physicians-industry ties.

Then, as we identified some outliers with implausible amounts, it was likely that the database contained some errors (e.g. some gifts may have been reported in cents by the company [outliers typically ending in two zeros]). It was therefore decided a posteriori to exclude amounts exceeding $100000 €(\$ 118000)$ for a single payment. It corresponds to 35 extreme 
medRxiv preprint doi: https://doi.org/10.1101/2021.05.07.21255795; this version posted May 11, 2021. The copyright holder for this preprint

(which was not certified by peer review) is the author/funder, who has granted medRxiv a license to display the preprint in perpetuity.

All rights reserved. No reuse allowed without permission.

observations ( 34 in 2019,1 in 2018 , i.e. $0.0005 \%$ of the gifts) and $32 \mathrm{m€}$ ( $4 \%$ of the total and $13 \%$ of 2019).

\section{Patient and public involvement}

Patients and public were involved throughout the French FORMINDEP association that aims to improve the independence of physicians' medical education. FORMINDEP's members (patients and physicians) kindly accepted to participate to the manuscript reviewing and editing. French CI3P organization (Patient and Public Partnership Innovation Center of the Faculty of Medicine of Nice) also accepted to participate to the manuscript reviewing and editing. Their comments enhanced the manuscript's quality, especially the discussion.

\section{RESULTS}

\section{Participants}

We identified 238 professional medical associations. 101 of them had produced clinical practice guidelines in 2018 and/or 2019 and two of them had no website or no board on their website. We identified $605 \mathrm{KOL}, 548$ of them were found on the Transparency in Healthcare database. The number of KOL in each professional medical association ranged from 1 to 12 , with a median of $6.12 \mathrm{KOL}$ belonged to more than one professional medical association. The way KOL were identified is described by the figure 1 : Flowchart.

\section{< PLEASE INSERT HERE FIG.1 : FLOWCHART >}

\section{Transparency in Healthcare public database}

The database contained $6 \mathrm{~b} €(\$ 7.1 \mathrm{~b})$ of ties over 8 years. Gifts represented $1.7 \mathrm{~b} €$, agreements represented $1.3 \mathrm{~b} €$ and remunerations represented $3 \mathrm{~b} € .{ }^{26} \mathrm{Gifts}$, agreements and remuneration are presented below from the year in which they were consistently declared, that is respectively since 2014, 2017 and 2017.

\section{Gifts (2014-2019)}

For all physicians 7354492 gifts were declared for a total amount of $818 \mathrm{~m} €(\$ 936 \mathrm{~m})$ from 2014 to 2019 . The median amount for a gift was $46 €(\mathrm{IQR}=25-60, \$ 54)$.

Most KOL (83\%) had at least one gift declared from 2014 to 2019. KOL's gifts represented $0.68 \%$ of the number of all physicians' gifts and $1.5 \%$ of the total amount of gifts, i.e. $12.3 \mathrm{~m} €$ $(\$ 14 \mathrm{~m})$. It represents a median of $€ 3700$ of gifts per KOL per year. The median amount for a KOL's gift was 60€ (IQR = 30-214).

Overall, the gifts declared to all physicians decreased in number and value from $1.3 \mathrm{~m}$ gifts $(151 \mathrm{~m} €)$ to 923000 gifts $(108 \mathrm{~m} €)$.

The number, value and proportion of gifts declared to KOL decreased from 9687 gifts ( $0.70 \%$ of the total number of gifts to physicians) / $2.2 \mathrm{~m} €$ ( $1.5 \%$ of the total value of gifts to physicians) to 6044 gifts ( $0.65 \%$ of the total number of gifts to physicians) / $1.5 \mathrm{~m} €$ (1.4\% of the total value of gifts to physicians).

The evolution year by year for each specific category of gift from 2014 to 2019 is presented in Table 2.

\section{$<$ PLEASE INSERT HERE TABLE $2>$}

Almost all (99\%) associations had at least one member of its board who had at least one declared gift since 2014. The median amount of gifts declared for all the corresponding 
medRxiv preprint doi: https://doi.org/10.1101/2021.05.07.21255795; this version posted May 11, 2021. The copyright holder for this preprint

(which was not certified by peer review) is the author/funder, who has granted medRxiv a license to display the preprint in perpetuity.

All rights reserved. No reuse allowed without permission.

KOL of a professional medical association was $61000 €(\mathrm{IQR}=14000-143000 ; \$ 70000)$ but varied widely between associations. $1 \%$ of the associations had no gift declared for their KOL, 16\% had less than $1000 €$ gifts per year for their KOL. 39\% had between $10000 €$ and $50000 €$ gifts and $11 \%$ had more than $50000 €$ gifts declared for their KOL each year.

\section{Agreements (2017-2019)}

Concerning non-KOL physicians, 1.67 millions agreements were declared for a total of $125 \mathrm{~m} €(\$ 143 \mathrm{~m})$ from 2017 to 2019 . There were 1.28 millions agreements $(77 \%)$ for which the reported amount was null. A null amount can be explained either by a report in one of the two other categories (when the agreement is linked with a gift or remuneration), or by a wrong declaration.

KOL's agreements represented $0.72 \%$ of all agreements declared to physicians and $2.5 \%$ of the value of these agreements, i.e. $3 \mathrm{~m} €(\$ 3,6 \mathrm{~m})$. It represents a median of $€ 1900$ of declared agreements per KOL per year. There were 9496 KOLs' agreements (79\%) for which the reported amount was null.

Overall, agreements declared to all physicians were increasing from $42 \mathrm{~m} €$ in 2017 to $43 m €$ in 2019.

The evolution year by year of the total amount, and median amount of agreements is presented in table 3.

\section{< PLEASE INSERT TABLE 3 HERE >}

The number, the value and the proportion of agreements declared to KOL decreased each year, from 4400 agreements $(0.78 \%$ of the number of agreements to physicians) / $1.1 \mathrm{~m} €$ (2.6\% of the value of agreements to physicians) in 2017 to 3500 agreements $(0.64 \%$ of the number of agreements to physicians ) / $1 \mathrm{~m} €$ ( $2.3 \%$ of the value of agreements to physicians) in 2019. This evolution is depicted in Figure 2.

\section{$<$ PLEASE INSERT FIGURE 2 HERE >}

The median amount of agreements declared to all the corresponding KOL of an association was $15900 €$ per year (IQR= 390 to 35617$)$.

\section{Remunerations (2017-2019)}

For all physicians, 250873 remunerations were declared totaling $156 \mathrm{~m} €(\$ 178 \mathrm{~m})$ from 2017 to 2019. The median amount for a remuneration was $250 €$ (IQR 55-742) (\$296). KOLs' perceived $2.3 \%$ of physicians' remunerations, i.e. $6.8 \mathrm{~m} €(\$ 7.8 \mathrm{~m})$ or $4.4 \%$ of the total value of remunerations to physicians. Overall, KOLs received 4 times more remunerations than other physicians, which represents a median of $€ 4100$ of remunerations per KOL per year.

Regarding all physicians, remunerations increased in number and total value but the median amount decreased sharply. The evolution of the total amount of remunerations is presented in table 3. Physicians' remunerations increased from 77277 remunerations / 49m€ in 2017 to 96160 remunerations / 54m€ in 2019.

The number, value and proportion of remunerations declared to KOL decreased each year from 2017 (1 900 remunerations, $2.5 \%$ of the number of remunerations to physicians, accounting for $2.3 \mathrm{~m} €$ and $4.8 \%$ of the value of remunerations to physicians) to 2019 (1 800 remunerations, $1.9 \%$ of the number of remunerations to physicians, accounting for $2.1 \mathrm{~m} €$ and $4 \%$ of the value of remunerations to physicians in 2019). 
medRxiv preprint doi: https://doi.org/10.1101/2021.05.07.21255795; this version posted May 11, 2021. The copyright holder for this preprint

(which was not certified by peer review) is the author/funder, who has granted medRxiv a license to display the preprint in perpetuity.

All rights reserved. No reuse allowed without permission.

The median amount of remunerations declared for all the corresponding KOL of an association was $21000 €$ per year (IQR 1012 - 68 977, \$25 000).

\section{DISCUSSION}

\section{Principle findings}

During this period, $818 \mathrm{~m} €$ of gifts, $125 \mathrm{~m} €$ of agreements and $156 \mathrm{~m} €$ of remunerations were declared to physicians in France. The amount of gifts decreased and the total amount of declared agreements and remunerations increased. Gifts represented the largest amount declared.

Almost every professional medical association included at least one KOL who received one or more gifts since 2014 (99\%) or 2017 (97\%). Over the whole period, the median amount of gifts per association was $€ 61000$ (\$70 000). From 2017 to 2019, the median cumulative amount for each professional medical association was $15900 €$ of agreements and 21 $900 €$ of remunerations. The number and amount of gifts varied widely from one association to another, ranging from $€ 0$ to $160000 €$ (\$189 000) for all the members of one association on the studied period.

The number, value and proportion of gifts, agreements and remunerations for KOLs were slightly decreasing over time. Remunerations represented the largest amount declared to KOLs with a median amount per capita 4 times higher than for other physicians. KOLs represented $0.24 \%$ of the physicians but were associated to $1.5 \%$ of the gifts, $2.4 \%$ of the agreements and $4.4 \%$ of the remunerations in value. It represents $€ 3700$ of gifts, $€ 1900$ of agreements and $€ 4100$ of remunerations per capita per year. This amount of agreements is probably underestimated since $79 \%$ of KOLs' agreements amount was declared null in the database (see above).

\section{Strengths and Limitations}

This study is exhaustive of all ties declared on the French Transparency in Healthcare database. All physicians practicing in France were included since ties are mandatory to declare.

However, the statements may be underestimated since many agreement's amounts were not available. Indeed, when a physician signs an agreement conferring an advantage, the amount can be declared either nil, in agreement, in gift or both in agreement and gift. There is no government control at this level.

The effect of this bias is difficult to predict : on the one hand, firms did not declare the amounts of thousands of agreements, thus underestimating the amounts received by physicians. On the other hand, the amount of an agreement could be double counted. The entire Eurofordocs database (with all beneficiaries, without time limitations) contains 5.5 million agreements, 3.3 million of which have a nil amount. 2.2 million gifts claim to be linked to an agreement, but have an invalid textual link. There are therefore at least 1.1 million agreements with a nil amount despite the legal obligation to declare it.

Another limitation lies in the fact that the data comes from the declarations of the pharmaceutical industry itself with typos. Moreover, there may be a delay in data reporting, and remunerations may have been misclassified as it was possible to declare them as gifts or as remunerations until October, 2017.

Finally, in the absence of an official definition, we choose an objective but restrictive definition of KOL which lead us to rule out many individuals of great leverage that could also be called KOL . 


\section{Comparison with other studies}

Our results are in line with those observed worldwide but adds new data regarding the French context. Very recent U.S. study showed that nearly three-quarters of the executives of the 10 most influential professional medical associations in the U.S. had ties with the pharmaceutical industry, with wide variations in the amount of payments reported between the professional medical associations. ${ }^{10}$ Total general payments of $\$ 24.8 \mathrm{~m}(20.8 \mathrm{~m} €$, $£ 18.9 \mathrm{~m})$ were linked to the $235 \mathrm{KOL}$ of the 10 most influential professional medical associations in 3 years. The total median general payment was $\$ 6000$ (IQR \$309 to \$54 000) (5000€, £4 500).

In this study, KOLs received 10 times more per capita per year in total amount than the French KOLs, and more than 83 times more in terms of median amount.

The amount of money involved in this American study seems to be much more important. This difference could be explained by societal differences but also by the fact that we included professional medical associations regardless of their size, cost or influence. On the other hand, this difference can be explained by the fact that USA represents a population 5 times larger and 4 times more physicians, which may constitutes an important return on investments. Finally, in the US, there are more mandatory payments to report, and there are enforcement measures and effective penalties. ${ }^{29}$

\section{Implications of this study}

Despite multiple calls for more distance, ${ }^{10,30-33}$ KOL have still privileged relationships with pharmaceutical industry. This phenomenon can lead to lower guidelines' quality and to a general loss of confidence in both KOL and physicians. Indeed, several guidelines were abrogated since there have been doubts about the independence of the experts involved in their writing. ${ }^{34-37}$ In turn, Chakroun et al. have shown that conflict of interests disclosure reduces public and physicians' trust in KOL. ${ }^{38}$ Experience shows that financial ties can also be instrumentalized to discredit any expert position, the link being used as an argument to call into question the scientific opinion.

Our study's finding of remaining concealment of the agreements amounts, despite the legal obligation to declare them, shows that transparency is still in progress and that both researchers and citizens do not yet have access to all data. For us, the main area for improvement would be to make it mandatory to report the amount of benefits and remunerations conferred by the agreement in the agreement section. Moreover, the declarations should be checked by the public authorities, which is the only guarantee of the reliability of the information provided.

Future research might focus on the correlation between the amount of gifts and the medical specialty or the cost of the concerned diseases. Further research is needed to identify other kinds of KOL such as the department heads of the teaching hospitals, and the medical university lecturers. Financial ties could be tracked over time, acting as a nudge to help chart moves towards independence.

\section{Acknowledgments}

We thank Pierre-Alain Jachiet for his proofreading of the manuscript, his help to fully understand the database and use properly EurosForDocs.

Patients and public were involved throughout the French FORMINDEP association that aims to improve the independence of physicians' medical education. FORMINDEP's members (patients and physicians) kindly accepted to participate to the manuscript reviewing and editing. French CI3P organization (Patient and Public Partnership Innovation Center of the Faculty of Medicine of Nice) also accepted to participate to the manuscript reviewing and editing. Their comments enhanced the manuscript's quality, especially the discussion. 


\section{Footnotes}

Funding : none

Competing interest : All authors have completed the ICMJE uniform disclosure form and declare: no support from any organisation for the submitted work, no financial relationships with any organisations that might have an interest in the submitted work in the previous three years, no other relationships or activities that could appear to have influenced the submitted work.

Author Contributions : $\mathrm{MC}$ and $\mathrm{AB}$ initiated and designed the study, searched the literature, interpreted the results and wrote the manuscript. AS performed the analysis, contributed to the study design and interpreted results. FN contributed to the study design and interpreted the results. AB is the garantor. All authors have critically revised the manuscript and approved the manuscript. The corresponding author attests that all listed authors meet authorship criteria and that no others meeting the criteria have been omitted.

Ethical approval : the French Commission Nationale Informatique et Libertés approved this study.

Data sharing statement : Data from EurosForDocs are available on https://www.eurosfordocs.fr/data\#donn-es. Analytic code from the study is available on https://osf.io/4756p/?view_only=df16d649d87847e5aa9478960620bf81

The guarantor (AB) affirms that the manuscript is an honest, accurate, and transparent account of the study being reported; that no important aspect of the study was omitted; and that any discrepancies from the study as originally planned have been explained.

Figures legend/Caption :

Figure 1. Flowchart, representing how KOL were identified by crossing three databases.

Figure 2. Evolution of the 3 kinds of financial ties for KOL and all physicians. The gifts declared to all physicians were decreasing in number and value over time; the number, the value and the proportion of gifts declared to KOL were decreasing. The agreements declared to all physicians were increasing; the number, the value and the proportion of agreements declared to KOL were decreasing. The remunerations declared to all physicians were increasing; the number, the value and the proportion of remunerations declared to KOL were decreasing.

\section{References}

1. Lundh A, Lexchin J, Mintzes B, Schroll JB, Bero L. Industry sponsorship and research outcome. Cochrane Database Syst Rev. 2017;2:MR000033. doi:10.1002/14651858.MR000033.pub3 
medRxiv preprint doi: https://doi.org/10.1101/2021.05.07.21255795; this version posted May 11, 2021. The copyright holder for this preprint (which was not certified by peer review) is the author/funder, who has granted medRxiv a license to display the preprint in perpetuity.

All rights reserved. No reuse allowed without permission.

2. Brunt CS. Physician characteristics, industry transfers, and pharmaceutical prescribing: Empirical evidence from medicare and the physician payment sunshine act. Health Serv Res. Published online October 1, 2018. doi:10.1111/1475-6773.13064

3. Hadland SE, Rivera-Aguirre A, Marshall BDL, Cerdá M. Association of Pharmaceutical Industry Marketing of Opioid Products With Mortality From Opioid-Related Overdoses. JAMA Netw Open. 2019;2(1):e186007. doi:10.1001/jamanetworkopen.2018.6007

4. DeJong C, Aguilar T, Tseng C-W, Lin GA, Boscardin WJ, Dudley RA. Pharmaceutical Industry-Sponsored Meals and Physician Prescribing Patterns for Medicare Beneficiaries. JAMA Intern Med. 2016;176(8):1114. doi:10.1001/jamainternmed.2016.2765

5. Goupil B, Balusson F, Naudet F, et al. Association between gifts from pharmaceutical companies to French general practitioners and their drug prescribing patterns in 2016: retrospective study using the French Transparency in Healthcare and National Health Data System databases. The BMJ. 2019;367. doi:10.1136/bmj.16015

6. Schott G, Dünnweber C, Mühlbauer B, Niebling W, Pachl H, Ludwig W-D. Does the Pharmaceutical Industry Influence Guidelines? Dtsch Ärztebl Int. 2013;110(35-36):575-583. doi:10.3238/arztebl.2013.0575

7. Horn J, Checketts JX, Jawhar O, Vassar M. Evaluation of Industry Relationships Among Authors of Otolaryngology Clinical Practice Guidelines. JAMA Otolaryngol Neck Surg. 2018;144(3):194-201. doi:10.1001/jamaoto.2017.2741

8. Combs TR, Scott J, Jorski A, Heavener T, Vassar M. Evaluation of Industry Relationships Among Authors of Clinical Practice Guidelines in Gastroenterology. JAMA Intern Med. 2018;178(12):1711-1712. doi:10.1001/jamainternmed.2018.4730

9. Checketts JX, Sims MT, Vassar M. Evaluating Industry Payments Among Dermatology Clinical Practice Guidelines Authors. JAMA Dermatol. 2017;153(12):1229-1235. doi:10.1001/jamadermatol.2017.3109

10. Moynihan R, Albarqouni L, Nangla C, Dunn AG, Lexchin J, Bero L. Financial ties between leaders of influential US professional medical associations and industry: cross sectional study. BMJ. 2020;369. doi:10.1136/bmj.m1505

11. Elder K, Turner KA, Cosgrove L, et al. Reporting of financial conflicts of interest by Canadian clinical practice guideline producers: a descriptive study. Can Med Assoc J. 2020;192(23):E617. doi:10.1503/cmaj.191737

12. LOI N ${ }^{\circ}$ 2011-2012 Du 29 Décembre 2011 Relative Au Renforcement de La Sécurité Sanitaire Du Médicament et Des Produits de Santé.; 2011.

13. Décret $\mathrm{n}^{\circ} 2016-1939$ du 28 décembre 2016 relatif à la déclaration publique d'intérêts prévue à l'article L. 1451-1 du code de la santé publique et à la transparence des avantages accordés par les entreprises produisant ou commercialisant des produits à finalité sanitaire et cosmétique destinés à l'homme | Legifrance. Accessed June 14, 2020. https://www.legifrance.gouv.fr/eli/decret/2016/12/28/AFSX1637582D/jo/texte

14. Fabbri A, Santos Ancel la, Mezinska S, Mulinari S, Mintzes B. Sunshine Policies and Murky Shadows in Europe: Disclosure of Pharmaceutical Industry Payments to Health Professionals in Nine European Countries. Int J Health Policy Manag. 2018;7(6):504-509. doi:10.15171/ijhpm.2018.20

15. Sismondo S. How to make opinion leaders and influence people. CMAJ Can Med Assoc J. 2015;187(10):759-760. doi:10.1503/cmaj.150032

16. Coleman J, Katz E. The Diffusion of an Innovation among Physicians! :18.

17. The Pharma Marketing Glossary. Pharma Marketing Network. Accessed July 19, 2020. https://www.pharma-mkting.com/glossary/

18. Moynihan R. Key opinion leaders: independent experts or drug representatives in disguise? BMJ. 2008;336(7658):1402-1403. doi:10.1136/bmj.39575.675787.651 
medRxiv preprint doi: https://doi.org/10.1101/2021.05.07.21255795; this version posted May 11, 2021. The copyright holder for this preprint (which was not certified by peer review) is the author/funder, who has granted medRxiv a license to display the preprint in perpetuity.

All rights reserved. No reuse allowed without permission.

19. Sismondo S. Key Opinion Leaders and the Corruption of Medical Knowledge: What the Sunshine Act Will and Won't Cast Light on. J Law Med Ethics. 2013;41(3):635-643. doi:10.1111/jlme.12073

20. Meffert JJ. Key opinion leaders: where they come from and how that affects the drugs you prescribe. Dermatol Ther. 2009;22(3):262-268. doi:10.1111/j.1529-8019.2009.01240.x

21. Revue Prescrire. Leaders d'opinion $\square$ : coûteux, mais rentables pour les firmes pharmaceutiques. 2005;25(266):777.

22. Revue Prescrire. Les leaders d'opinion, instrument marketing des firmes. Rev Prescrire. 2012;32(341):219.

23. Société savante - CISMeF. Accessed June 14, 2020. http://www.churouen.fr/page/cismef-type-ressource/societe-savante

24. Liste de sociétés savantes scientifiques en France. Accessed June 14, 2020. http://dictionnaire.sensagent.leparisien.fr/LISTE\%20DE\%20SOCIETES\%20SAVANTES\%2

OSCIENTIFIQUES\%20EN\%20FRANCE/fr-fr/

25. Nouveautés, consensus et lignes directrices - Bmlweb. Accessed June 14, 2020. http://www.bmlweb.org/nouveaute.html

26. Euros for Docs - vison par professionnel bénéficiaire. Accessed June 14, 2020. https://www.eurosfordocs.fr/metabase/dashboard/2

27. Traitement des données EurosforDocs. Euros For Docs. Accessed June 14, 2020. https://www.eurosfordocs.fr/data/

28. R Development Core Team (2005). R: A language and environment for statistical computing. R Foundation for Statistical Computing, Vienna, Austria. ISBN 3-900051-07-0, URL: $\quad$ http://www.R-project.org. Accessed August 2020. https://wp.unil.ch/asi/documentation/citer-r-dans-un-rapport/

29. Rapport $\square$ : La prévention des conflits d'intérêts en matière d'expertise sanitaire - mars 2016. Accessed August 2020. https://www.ccomptes.fr/sites/default/files/EzPublish/20160323-prevention-conflits-interetsen-matiere-expertise-sanitaire.pdf\#page $=65$

30. Fava GA. Should the drug industry work with key opinion leaders? No. BMJ. 2008;336(7658):1405. doi:10.1136/bmj.39541.731493.59

31. Sculier J-P. Conflits d'intérêt $\square$ : une notion souvent (volontairement) ignorée des médecins Conflicts of interest $\square$ : a concept often (voluntary) ignored by physicians. Rev Med Brux. 2010;(31):199-205.

32. Wilson M. The Sunshine Act: Commercial conflicts of interest and the limits of transparency. Open Med. 2014;8(1):e10-e13.

33. Moynihan R, Bero L, Hill S, et al. Pathways to independence: towards producing and using trustworthy evidence. BMJ. 2019;367. doi:10.1136/bmj.16576

34. Décision n ${ }^{\circ} 2011.05 .064 / \mathrm{MJ}$ du 18 mai 2011 du Collège de la Haute Autorité de Santé portant abrogation de la recommandation « $\square$ Diagnostic et prise en charge de la maladie d'Alzheimer et des maladies apparentées $\square$ ». Haute Autorité de Santé. Accessed November 9, 2020. https://webzine.has-sante.fr/jcms/c_1056866/fr/decision-n2011-05-064/mj-du-18-mai2011-du-college-de-la-haute-autorite-de-sante-portant-abrogation-de-la-recommandationdiagnostic-et-prise-en-charge-de-la-maladie-d-alzheimer-et-des-maladies-apparentees 35. Dyslipidémies $\square$ : face au doute sur l'impartialité de certains de ses experts, la HAS abroge sa recommandation. Haute Autorité de Santé. Accessed August 5, 2020. https://www.has-sante.fr/jcms/c_2885402/fr/dyslipidemies-face-au-doute-sur-l-impartialitede-certains-de-ses-experts-la-has-abroge-sa-recommandation

36. Traitement médicamenteux du diabète de type $2 \square$ : recommandation retirée le 2 mai 2011. Haute Autorité de Santé. Accessed August 5, 2020. https://www.has- 
sante.fr/jcms/c_459270/fr/traitement-medicamenteux-du-diabete-de-type-2-recommandationretiree-le-2-mai-2011

37. Barbaroux A, Jedat V. Lifelong continuing education. Critical analysis of scientific and medical information. Management of links of interest. exercer 2020;163:233-6.

38. Chakroun R, Milhabet I. Medical opinion leaders conflict of interests: effects of disclosures on the trust of the public and general practitioners. Rev Epidemiol Sante Publique. 2011;59(4):233-242. doi:10.1016/j.respe.2010.12.011

39. Conflits d'intérêts $\square$ : Karine Lacombe répond à Didier Raoult. egora.fr. Published June 26, 2020. Accessed August 5, 2020. https://www.egora.fr/actus-pro/santepublique/59825-conflits-d-interets-karine-lacombe-repond-a-didier-raoult

40. Girard E. 118.000 euros de MSD, 116.000 euros de Roche $\square$ : faut-il s'inquiéter des liens entre labos et conseils scientifiques $\square$ ? Marianne. Published April 3, 2020. Accessed August 5, 2020. https://www.marianne.net/societe/118000-euros-de-msd-116000-euros-deroche-faut-il-s-inquieter-des-liens-entre-labos-et

41. Sallet F, Lebossé V, Toulemonde M. \#TransparenceCHU $\square$ : comment nous avons enquêté sur les liens entre labos et médecins. leparisien.fr. Published January 10, 2020. Accessed August 6, 2020. https://www.leparisien.fr/economie/transparencechu-comment-nousavons-enquete-sur-les-liens-entre-labos-et-medecins-10-01-2020-8233257.php 
medRxiv preprint doi: https://doi.org/10.1101/2021.05.07.21255795; this version posted May 11, 2021. The copyright holder for this preprint (which was not certified by peer review) is the author/funder, who has granted medRxiv a license to display the preprint in perpetuity. All rights reserved. No reuse allowed without permission.

Table 1 presents the 3 categories of links of interest and the date from where they had to be declared on the Transparency in Healthcare database (base Transparence Santé). The Transparency in Healthcare database was laid down in the "Strengthening the safety of medicines and health products" law of December, 2011, and launched in July, 2014.

\begin{tabular}{|l|l|l|}
\hline Type of ties & Definition & Information mandatory to declare \\
\hline Gifts & $\begin{array}{l}\text { Anything that is allocated or paid without consideration by a } \\
\text { company to a health actor, with a value of more than 10 euros } \\
\text { including taxes. Available categories on the website = gifts, } \\
\text { contribution to the cost of promotional, scientific or professional } \\
\text { events, accommodation, hospitality, catering, transport, transport } \\
\text { and hospitality, in-kind donations, donations, donations of mon- } \\
\text { ey, grants, training, expenditures for services and advice, fees, } \\
\text { failed category association, empty, other. }\end{array}$ & $\begin{array}{l}\text { Identity of the parties concerned, amount, nature and date of } \\
\text { each benefit. Mandatory since the law of 2013; actual website } \\
\text { availability in 2014. }\end{array}$ \\
\hline Agreements & $\begin{array}{l}\text { Contracts involving obligations on the part of the physician and } \\
\text { the industry. For example, participation in a congress as a speak- } \\
\text { er (obligation fulfilled by the professional), with payment for } \\
\text { transport and accommodation (obligation fulfilled by the compa- } \\
\text { ny). The conventions concern research activities, clinical trials, } \\
\text { participation in a scientific congress, training activities, etc. }\end{array}$ & $\begin{array}{l}\text { Identity of the parties concerned, the organizer, the name, date } \\
\text { and place of the event, date of the agreement, its precise pur- } \\
\text { pose (mandatory since the law of 2013; actual website availa- } \\
\text { bility 2014) and the amount (mandatory since the law of 2016, } \\
\text { actual website availability in 2017). If the agreements give rise } \\
\text { to payments in benefits or remuneration, the payments can be } \\
\text { indicated in the category agreements or in benefits or remu- } \\
\text { neration, with a numerical link to the agreement. }\end{array}$ \\
\hline Remunerations & $\begin{array}{l}\text { Payment for work or services with a value of more than 10 euros } \\
\text { including taxes. }\end{array}$ & $\begin{array}{l}\text { Identity of the parties, final beneficiary, date of payment, } \\
\text { amount if it is greater than or equal to 10euros (available since } \\
\text { 2015 but mandatory since the law of 2016, actual website } \\
\text { availability in the remuneration section in 2017). }\end{array}$ \\
\hline
\end{tabular}


medRxiv preprint doi: https://doi.org/10.1101/2021.05.07.21255795; this version posted May 11, 2021. The copyright holder for this preprint (which was not certified by peer review) is the author/funder, who has granted medRxiv a license to display the preprint in perpetuity. All rights reserved. No reuse allowed without permission.

Table 2. Median (IQR) amount of gifts to KOL and non-KOL physicians in euros (€).

\begin{tabular}{|c|c|c|c|c|c|c|c|}
\hline Gifts category & \begin{tabular}{|l}
$\begin{array}{l}\text { Physicians } \\
\text { category }\end{array}$ \\
\end{tabular} & 2014 & 2015 & 2016 & 2017 & 2018 & 2019 \\
\hline \multirow[t]{2}{*}{ Accommodation } & $\begin{array}{l}\text { All physi- } \\
\text { cians }\end{array}$ & $210(165-314)$ & $\begin{array}{l}215(165- \\
341)\end{array}$ & $\begin{array}{l}215(170- \\
314)\end{array}$ & $\begin{array}{l}215(164- \\
323)\end{array}$ & $\begin{array}{l}221(170- \\
349)\end{array}$ & $\begin{array}{l}218(173- \\
328)\end{array}$ \\
\hline & KOL & $\begin{array}{l}218(172- \\
305)\end{array}$ & $\begin{array}{l}220(170- \\
330)\end{array}$ & $\begin{array}{l}218(179- \\
296)\end{array}$ & $\begin{array}{l}226(176- \\
313)\end{array}$ & $\begin{array}{l}221(175- \\
323)\end{array}$ & $\begin{array}{l}229(180- \\
344)\end{array}$ \\
\hline \multirow[t]{2}{*}{ Hospitality } & $\begin{array}{l}\text { All physi- } \\
\text { cians }\end{array}$ & $50(27-118)$ & $45(25-60)$ & $46(24-60)$ & $55(30-60)$ & $53(28-60)$ & $52(28-60)$ \\
\hline & KOL & $70(30-448)$ & $\begin{array}{l}58(28.2- \\
258)\end{array}$ & $60(30-258)$ & $\begin{array}{l}80.5(40- \\
362)\end{array}$ & $60(29-319)$ & $60(30-329)$ \\
\hline \multirow[t]{2}{*}{ Catering } & $\begin{array}{l}\text { All physi- } \\
\text { cians }\end{array}$ & $40(24-55)$ & $40(24-56)$ & $38(23-55)$ & $38(23-56)$ & $38(23-56)$ & $38(24-57)$ \\
\hline & $K O L$ & $40(23-59)$ & $40(23-59)$ & $40(23-58)$ & $40(23-58)$ & $40(24-59)$ & $40(24-59)$ \\
\hline \multirow[t]{2}{*}{ Transport } & $\begin{array}{l}\text { All physi- } \\
\text { cians }\end{array}$ & $208(91-420)$ & $200(88-398)$ & $191(85-380)$ & $189(79-357)$ & $182(81-344)$ & $177(77-332)$ \\
\hline & KOL & $202(70-471)$ & $\begin{array}{l}206(74.2- \\
461)\end{array}$ & $244(96-477)$ & $207(77-445)$ & $\begin{array}{l}198(79.8- \\
414)\end{array}$ & $187(71-395)$ \\
\hline \multirow{2}{*}{$\begin{array}{l}\text { Contributions } \\
\text { to the cost of } \\
\text { promotional } \\
\text { events }\end{array}$} & $\begin{array}{l}\text { All physi- } \\
\text { cians }\end{array}$ & $60(50-400)$ & $60(50-404)$ & $60(44-400)$ & $200(55-455)$ & $\begin{array}{l}400(250- \\
590)\end{array}$ & $\begin{array}{l}440(260- \\
650)\end{array}$ \\
\hline & $K O L$ & $320(60-591)$ & $350(60-600)$ & $390(87-650)$ & $\begin{array}{l}450(186- \\
729)\end{array}$ & $\begin{array}{l}470(290- \\
740)\end{array}$ & $\begin{array}{l}538(290- \\
796)\end{array}$ \\
\hline \multirow{2}{*}{$\begin{array}{l}\text { Donations- } \\
\text { Grants- } \\
\text { Training }\end{array}$} & $\begin{array}{l}\text { All physi- } \\
\text { cians }\end{array}$ & $21(17-30)$ & $23(17-50)$ & $36(23-94)$ & $62(30-171)$ & $55(29-171)$ & $55(25-144)$ \\
\hline & KOL & $83(60-275)$ & $\begin{array}{l}68(27.5- \\
1578)\end{array}$ & $96(63.5-138)$ & $76(45-192)$ & $155(42-225)$ & $80(42-180)$ \\
\hline \multirow[t]{2}{*}{$\begin{array}{l}\text { Service and } \\
\text { consulting }\end{array}$} & $\begin{array}{l}\text { All physi- } \\
\text { cians }\end{array}$ & $26(22-30)$ & $30(22-45)$ & $30(24-50)$ & $30(25-40)$ & $50(25-80)$ & $116(40-362)$ \\
\hline & KOL & $30(24-120)$ & $47(29-325)$ & $65(30-600)$ & $32(25-83)$ & $130(74-309)$ & $158(69-506)$ \\
\hline \multirow[t]{2}{*}{ Other } & $\begin{array}{l}\text { All physi- } \\
\text { cians }\end{array}$ & $100(30-350)$ & $140(30-496)$ & $100(19-375)$ & $22(16-84)$ & $25(16-104)$ & $49(16-220)$ \\
\hline & KOL & $\begin{array}{l}337(34.8- \\
1000)\end{array}$ & $\begin{array}{l}800(195- \\
1188)\end{array}$ & $\begin{array}{l}700(100- \\
1000)\end{array}$ & $310(23-915)$ & $40(12-153)$ & $\begin{array}{l}79.5(12- \\
500)\end{array}$ \\
\hline \multirow[t]{2}{*}{ TOTAL } & $\begin{array}{l}\text { All physi- } \\
\text { cians }\end{array}$ & $45(25-60)$ & $45(25-60)$ & $45(25-60)$ & $46(25-60)$ & $48(25-60)$ & $49(26-60)$ \\
\hline & KOL & $59(29-198)$ & $60(30-224)$ & $60(30-217)$ & $60(30-213)$ & $60(31-214)$ & $60(31-210)$ \\
\hline
\end{tabular}


medRxiv preprint doi: https://doi.org/10.1101/2021.05.07.21255795; this version posted May 11, 2021. The copyright holder for this preprint (which was not certified by peer review) is the author/funder, who has granted medRxiv a license to display the preprint in perpetuity.

All rights reserved. No reuse allowed without permission.

Table 3. Total amount, and median (IQR) amount of agreements, total and median (IQR) amount of remunerations to KOL and non-KOL physicians, year by year since they are consistently declared.

\begin{tabular}{|c|c|c|c|c|c|c|}
\hline $\begin{array}{l}\text { Payment cat- } \\
\text { egory }\end{array}$ & $\begin{array}{c}\text { Physicians } \\
\text { category }\end{array}$ & Amount & 2017 & 2018 & 2019 & Total \\
\hline \multirow[t]{6}{*}{ Agreements } & \multirow[t]{3}{*}{$\begin{array}{l}\text { All physi- } \\
\text { cians }\end{array}$} & $\begin{array}{l}\text { Number of agreements } \\
\text { for which the amount } \\
\text { could not be found in the } \\
\text { agreement section (per- } \\
\text { centage of the number of } \\
\text { agreements) }\end{array}$ & $446204(79 \%)$ & $443687(79 \%)$ & $394393(72 \%)$ & 1284284 \\
\hline & & $\begin{array}{l}\text { Total value of agree- } \\
\text { ments for which an } \\
\text { amount could be found } \\
\text { in the agreement section } \\
\text { in } €\end{array}$ & 42905877 & 39962079 & 43098150 & $\begin{array}{c}125966 \\
106\end{array}$ \\
\hline & & $\begin{array}{l}\text { Number of agreements } \\
\text { with a declared amount } \\
\text { in the agreement section }\end{array}$ & 118860 & 119844 & 150987 & 389691 \\
\hline & \multirow[t]{3}{*}{$K O L$} & $\begin{array}{l}\text { Number of agreements } \\
\text { for which the amount } \\
\text { could not be found in the } \\
\text { agreement section (per- } \\
\text { centage of the number of } \\
\text { agreements) }\end{array}$ & $3514(80 \%)$ & $3319(80 \%)$ & $2663(76 \%)$ & 9496 \\
\hline & & $\begin{array}{l}\text { Total value of agree- } \\
\text { ments for which an } \\
\text { amount could be found } \\
\text { in the agreement section } \\
\text { in } €\end{array}$ & 1123947 & 1040295 & 1000651 & 3164893 \\
\hline & & $\begin{array}{l}\text { Number of agreements } \\
\text { with a declared amount } \\
\text { in the agreement section }\end{array}$ & 903 & 837 & 843 & 2583 \\
\hline \multirow[t]{6}{*}{$\underline{\text { Remunerations }}$} & \multirow[t]{3}{*}{$\begin{array}{l}\text { All physi- } \\
\text { cians }\end{array}$} & Total amount in $€$ & 49152264 & 53142546 & 54254342 & $\begin{array}{c}156549 \\
152\end{array}$ \\
\hline & & Median (IQR) & $300(65-750)$ & $350(65-800)$ & $130(50-613)$ & 250 \\
\hline & & $\begin{array}{l}\text { Number of remunera- } \\
\text { tions }\end{array}$ & 77277 & 77436 & 96160 & 250573 \\
\hline & \multirow[t]{3}{*}{$K O L$} & Total amount in $€$ & 2355894 & 2346293 & 2172827 & 6875014 \\
\hline & & Median (IQR) & $946(527-1440)$ & $\begin{array}{c}1000(600- \\
1497)\end{array}$ & $998(538-1375)$ & 1000 \\
\hline & & $\begin{array}{l}\text { Number of remunera- } \\
\text { tions }\end{array}$ & 1950 & 1901 & 1876 & 5718 \\
\hline
\end{tabular}

